This is an Accepted Manuscript of an article published by Taylor \& Francis Group in The Journal of Field Archaeology on 1 Sept, 2018, available at:

https://www.tandfonline.com/doi/abs/10.1080/00934690.2018.1503034

\title{
Urbanism and Residential Patterning in Angkor
}

Alison Carter, University of Oregon, Eugene, Oregon

Piphal Heng, University of Hawai'i-Mānoa, Mānoa, Hawai'i

Miriam Stark, University of Hawai'i-Mānoa, Mānoa, Hawai'i

Rachna Chhay, Angkor International Centre of Research and Documentation, APSARA National

Authority, Siem Reap, Cambodia

Damian Evans, École française d'Extrême-Orient, Paris, France

\begin{abstract}
The Khmer Empire (9th-15th centuries A.D.), centered on the Greater Angkor region, was the most extensive political entity in the history of mainland Southeast Asia. Stone temples constructed by Angkorian kings and elites were widely assumed to have been loci of ritual as well as habitation, though the latter has been poorly documented archaeologically. In this paper, we present the results of two field seasons of excavation at the temple site of Ta Prohm. Using LiDAR data to focus our excavations, we offer evidence for residential occupation within the temple enclosure from before the 11th century A.D. until the 14th century. A comparison with previous work exploring habitation areas within the Angkor Wat temple enclosure highlights similarities and differences between the two temples. We argue that temple habitation was a key component of the Angkorian urban system and that investigating this unique form of urbanism expands current comparative research on the diversity of ancient cities.
\end{abstract}

KEYWORDS: Angkor, Cambodia, urbanism, LiDAR, community planning 


\section{Introduction}

The Angkorian state, based in what is now Cambodia, dominated much of mainland Southeast Asia from the 9th through 15th centuries A.D. For most of this period, the seat of royal power lay just north of the Tonle Sap Lake. Archaeological research in that area, which we call Greater Angkor, suggests it was a planned urban "landscape of power" (Osborne 2015: 15), the myriad monumental architectural features of which were inspired by Indic cosmology and complemented by a complex water management network (Evans et al. 2007, 2013; Fletcher, Penny, et al. 2008; Kummu 2009). Angkor's monumental temples, its art traditions, and its inscriptions have inspired several generations of scholars (Groslier 1956; Jacques and Freeman 2009). Who lived at Angkor and how they organized themselves have been subjects of speculation since the mid 20th century (Coe 1957; Groslier 1974). Comparative archaeologists and urban historians frequently acknowledge Angkor's value as an urban case study (Smith 2009; Wheatley 1971), but geopolitics prevented field-based research until recently (Carter et al. 2014; Stark and Griffin 2004: 121-122). In the last two decades, a major focus of the Greater Angkor Project has been the documentation of occupation traces within a ca. 3000 square kilometer study area that encompasses the Greater Angkor region (Evans et al. 2007; Fletcher 2000-2001).

The urban core of Angkor is largely identified by the concentration of stone temple precincts which were embedded within a complex hydraulic network of tanks, linear canal segments and embankment features that collectively formed the Angkorian civic-ceremonial center (Evans et al. 2013: 4; Fletcher et al. 2003; Hawken 2007; Pottier 1999). A recent LiDAR survey has revealed that the orthogonally-arranged central monument zone measures approximately $35 \mathrm{~km}^{2}$ (Evans et al. 2013). This urban epicenter was surrounded by a vast periphery of ponds, temples, and habitation mounds given functional coherence by an extended infrastructural network stretching over 1000-1500 km (Evans et al. 2007).

One of the most significant stone temples within the central monument zone of Angkor is Ta Prohm, lying approximately $1.5 \mathrm{~km}$ east of the walls of Angkor Thom and $3 \mathrm{~km}$ northeast of the temple of Angkor Wat (FIGURE 1). Ta Prohm was consecrated in the late 12th century by the ruler Jayavarman VII, and was an active monastery devoted to Buddhist teaching and learning. An inscription (designated K. 273) found here elaborates on the organization and functioning of the temple in a degree of detail found at no other site, including a description of those who worked - and may have lived - within the temple enclosure. Angkorian residences, even the king's royal palace, were constructed mostly out of perishable organic materials; therefore, this aspect of Angkorian life has remained largely invisible. Given their vast size and inscriptional discussions of the large numbers of people associated with the temples, scholars have often assumed that people lived within temple enclosures, but verifying this requires archaeological investigation.

In this paper we present the first archaeological evidence for occupation within the temple enclosure of Ta Prohm. The fieldwork described here includes the first systematic excavations within the Ta Prohm temple enclosure and the first focused solely on investigating whether this space was used for residential occupation. Combined with prior work on habitation at Angkor Wat (Stark et al. 2015), we argue that habitation within temple enclosures was an important component of the settlement organization found at Angkor. Fieldwork was conducted as part of the Greater Angkor Project (hereafter GAP) and builds on prior work on macro-urban organization across Greater Angkor (Evans et al. 2013; Hawken 2013). We begin by discussing changing conceptions of Angkorian urbanism, explore views on the functions of the stone temple 
enclosures, and then present the results of the GAP's fieldwork within the temple enclosure of Ta Prohm. We then compare habitation at Ta Prohm with that documented at Angkor Wat to identify similarities and differences in the use of temple residential spaces. Our field-based investigations suggest that temple enclosures varied within a single ruler's building program, and that residents modified these spaces through time. Temple enclosures were also well integrated within the highly structured orthogonal city grids that emerged as land tenure and spatial organization became more formalized in the 11th-13th centuries (Coedès and Dupont 1943: 105, note 2; Vickery 1998: 312). We argue that residential occupation of temple enclosures adds depth not only to our understanding of Southeast Asian cities, but also to comparative discussions of variability in ancient urban organization (Fisher and Creekmore 2014).

\section{Conceptions of Urbanism at Angkor}

From the late 19th to mid 20th centuries the focus of archaeological investigation at Angkor was the stone temples within the civic-ceremonial center, with little consideration of Angkor's integration within a broader landscape (Evans 2007). Early scholars and historians commonly described areas around Angkorian temples as cities or temple-cities (Briggs 1951: 210, 221; Coe 1957: 410; Coedès 1941; Stern 1951), an assertion also repeated by more recent scholars (Jacques 1978, 1997: 138-142; Jacques and Lafond 2007: 240) even in the absence of compelling evidence.

Other scholars have argued that Angkor's urban core was more sparsely inhabited. Miksic (2000) described Angkor as a classic orthogenetic city, with a focus on ritual functions and a small permanent population primarily consisting of elites and bureaucrats. Gaucher (2003: 31) has argued that temples were a "citadel of the gods" but were decidedly not cities. In his view, the only real urban center within Angkor was the 900-hectare walled enclosure of Angkor Thom (FIGURE 1). Within Angkor Thom's walls was an enclosed royal palace precinct and several stone temples, including the central state temple of Jayavarman VII, the Bayon.

Additionally, there was a planned town with organized grid system of roads, occupation mounds, and hydraulic features (Gaucher 2002, 2003). At this stage, however, the timing and nature of occupation within Angkor Thom require further archaeological investigation.

It was not until the work of French archaeologist B. P. Groslier that scholarly understanding of the urban boundaries of Angkor expanded to include the landscape around the temples. Groslier (1979; Groslier et al. 2007) envisioned Angkor as a "hydraulic city" in which the central monumental zone was integrated into a larger hydraulic infrastructure that included suburbs and agricultural land, and that this region may have held a population of up to a million people (Groslier 1979; Evans 2007: 4). Groslier was unable to verify his hypothesis with the necessary fieldwork due to socio-political unrest in the region and his untimely death.

During the 1990s, archaeologists were able to use aerial photographs, aerial radar imaging, and ground survey to build a more comprehensive map of the Angkorian landscape (Fletcher and Pottier 2002; Pottier 1999). Multiple researchers have identified that by the 11th12th centuries A.D., the central monument zone was organized along an orthogonal grid (Evans et al. 2013: 12597-12598; Gaucher 2004; Pottier 1999, 2000, 2012), with higher population densities than the surrounding peripheral landscape, specialized administrative and religious functions, and markets. The current comprehensive map of the extended city-region encompasses $3000 \mathrm{~km}^{2}$, using the watershed catchments of Angkor's rivers to define the boundaries of what is conventionally known as Greater Angkor (Evans 2007; Evans et al. 2007). 
With this new map of Angkor has come a shift in our understanding of Angkorian urban organization. A sprawling residential pattern of scattered small temples, ponds, and house mounds was identified in the agricultural areas surrounding the central monument zone (Evans et al. 2007; Fletcher and Pottier 2002; Fletcher et al. 2003). In fact, this residential pattern extends beyond the boundaries of the water catchments to the northwest and southeast (Evans et al. 2007: 14279-14280). However, an area of approximately $1000-1500 \mathrm{~km}^{2}$, from the central monument core to the scattered rural hamlets, is well-integrated within a massive hydraulic network (Evans et al. 2007; Fletcher, Penny, et al. 2008; Fletcher, Pottier, et al. 2008). This has led some scholars to argue that Angkor is one of the world's largest low-density urban complexes (Evans et al. 2007; Fletcher 2009, 2012;

Fletcher et al. 2003; Hawken 2007; Lucero et al. 2015). Low-density urban forms consist of dispersed settlements, but contain an urban infrastructure, with poorly-defined boundaries between urban, periurban or suburban, and rural areas. The fact that open spaces (often for urban gardens, as discussed by Stark [2014]) frequently characterize the urban peripheries of lowdensity cities has led some scholars to view this urban form as a type of "agro-urban landscape" (Isendahl 2012) or "high-density ruralism" (Qadeer 2000).

Scholars have argued that that this massive hydraulic network integrated the outlying residential and agricultural landscape with the urban core and thus "ccreated' Greater Angkor as a corporate entity" (Evans et al. 2007: 14279). Although parts of the landscape have higher occupation densities than others, and the settlement can be structured quite differently in different areas, boundaries between these zones are often indistinct. The current map of Angkor is, of course, a palimpsest and ongoing research aims to understand the occupation history of this landscape over time, which will in turn give greater nuance to our understandings of Angkorian urbanism (Klassen 2018).

The goal of the current study is not to argue for or against Angkor's status as a lowdensity urban complex, but rather, to present archaeological data that adds more detail to our understanding of occupation at Angkor at the most granular and fundamental level, at the scale of the household or neighborhood. We use the temple enclosure of Ta Prohm as a case study for urban structure, using multiple archaeological approaches. Our findings demonstrate that the areas within temple enclosures were both ritual centers and important residential zones, although we disagree with their characterization as "temple-cities." Angkorian temple complexes had infrastructural features, but thus far appear to lack the urban "anatomy" (Cowgill 2004: 538-539) that typifies cities, like craft production areas, markets, or ethnic enclaves (although see Hendrickson and Evans [2015] for discussion of iron production within the temple complex of Preah Khan of Kampong Svay). Instead we view these spaces as "civic-ceremonial zones" (Smith 2010: 138) and key components of pre-modern urbanism at Angkor. Temple enclosures were a type of neighborhood or district in which residents were organized around the state architecture of the temple, and would have routinely interacted, both within their residential areas but also perhaps due to their occupational relationship with the temple (Smith 2010). These areas were foci for the royal-ritual organization of space, offering higher-density residential centers within an otherwise dispersed settlement pattern.

\section{Angkorian temples and the temple of Ta Prohm}

Construction of stone temples was an important component of the Angkorian rulers' developmental agenda or "rhythm" (Stern 1951). Rulers established their legitimacy by founding state temples whose grounds contained multiple structures and were often walled. State temples 
were dedicated to Hindu and, especially later in the sequence, Buddhist deities as well as rulers' ancestors (Roveda 2005; Stern 1951) and took two primary forms: tiered royal "templemountains" and sprawling horizontal edifices. Possibly representing cosmograms of the Hindu universe (Filliozat 1951; Mannikka 1996), they also served as loci of religious practice that drew rural populations to the city for annual festivals and pageantry (Stark 2015).

Inscriptional data suggests that Angkorian temples served multiple functions: they were places built by Angkorian elites and rulers for worship, but also frequently acted as universities focusing on religious study. Temples were also a key component of the Angkorian economy, overseeing tracts of land and receiving numerous temple donations. They also organized and relied on the labor of large numbers of personnel, some of who may have lived on the temple grounds (Lustig and Lustig 2015; Sahai 2012; Sedov 1978).

The temple complex of Ta Prohm was built by King Jayavarman VII, one of Angkor's most famous rulers and prolific builders, who ruled from 1181-1218 A.D. It was consecrated with the name Rajavihara, meaning "royal monastery", and was dedicated to Jayavarman VII's mother, who was represented as the Buddhist deity Prajnaparamita. The Ta Prohm complex is divided into a series of five nested enclosures (Bruguier 1998: 174), containing an inner stone sanctuary (FIGURE 2). A laterite wall, measuring approximately $1020 \times 670 \mathrm{~m}$, encloses an area of approximately 68 ha known as the outermost or fifth enclosure. Trees currently cover most of the area between the fifth and fourth enclosures, save for its easternmost portion. The central temple complex covers an area of approximately 5 ha and includes an additional four enclosures, which may have served varying functions (Briggs 1951: 213) (a more detailed description of the layout can be found in Kapur and Sahai [2007]). The temple itself is flat, being laid out all on one plane, in contrast to the pyramidal "temple-mountains" found elsewhere at Angkor.

Ta Prohm is one of Jayavarman's most famous temples in part because of its inscription (K. 273). The inscription records the date of Ta Prohm's consecration in 1186 A.D., but the exact start-date of its construction remains unclear (Coedès 1906: 47-48; Cunin 2013; Jacques 2007: 45, 2008: 7; Jacques and Lafond 2007: 240, 242; Vickery 2007: 18-22). Regardless of the exact year(s) of construction, we can generally date the Ta Prohm temple to the reign of Jayavarman VII in the late 12th century A.D.

The inscription notes a total of 79,365 people who serviced the temple, including people of Khmer, Burmese, and Cham ethnicities (some of whom may have been prisoners of war), as well as 18 high priests, 2740 officials, 2232 assistants, and 615 dancers. Overall, 12,640 individuals were directly associated with the functions of the temple. Notably, the inscription describes 1409 students and their lecturers as residents (Bhadri 2007: 53, K.273 stanza 82); it is not clear if others affiliated with the temple also lived within the enclosure. Items associated with life at the temple are also mentioned, including bedspreads, cushions, mosquito nets, and "Chinese beds of grass" (Bhadri 2007: stanza 109). Additionally, large quantities of perishable goods are itemized, some of which were supplied by the state and surrounding villages, which have thus far been invisible in the archaeological record. These include sesame, rice, black pepper, honey, wax and wax candles, kidney beans, clarified butter, yogurt, and milk. These details provide tantalizing clues to aspects of life that are not readily visible and require careful sub-surface archaeological investigations.

Little is known of Ta Prohm beyond Jayavarman VII's reign during the late Angkorian to post-Angkorian periods. Buddhist images at Ta Prohm were systematically vandalized sometime in the 13th century during a period of iconoclasm against Mahayana Buddhism, which saw the widespread destruction and defacement of Buddhist images across Angkor (Roveda 2004). When 
French explorers encountered Ta Prohm in the 19th century, they described it as abandoned and overgrown (Mouhot 1864).

\section{Angkorian residences}

In Cambodia, in both the past and the present, houses are normally built on stilts using wood and perishable materials (Tainturier 2006), making the identification of house structures archaeologically difficult. Nevertheless, archaeological findings can provide some clues regarding house form. Houses in both early and modern Southeast Asia typically cluster on mounds (typically communal mounds shared by an entire neighborhood) that are elevated above the flooded fields and other inundated areas; remnant traces of Angkorian mounds can be readily identified by looking at spatial patterning of the topography. Post-holes from a house built on piles or stilts dating from 1800-1300 B.C. were identified in western Thailand (Henriksen 1982), suggesting this house form has a deep history in Southeast Asia. Angkorian artists depict similar pile-built dwellings in bas-reliefs on the Bayon temple. More recent excavations near the Siem Reap airport have uncovered residential areas and postholes belonging to houses (Bâty and Bolle 2005; Bâty et al. 2014). This work provides a model for a rural Angkorian house, which included a house garden and was surrounded by economic trees. A small number of postholes and occupation evidence have also been found during excavations at the site of Tumnup Barang (Fletcher et al. 2003: 109-110) and Angkor Wat (Stark et al. 2015). Occupational evidence including hearths, pits, roof tiles, and animal remains were reported near the site of Prasat Tromoung, a Jayavarman VII hospital chapel located west of the Angkor Thom moat (Pottier and Chhem 2008).

Perhaps the most useful discussion of Angkorian houses comes from the writings of a Chinese emissary, Zhou Daguan, who visited Angkor in 1296 A . D . In this text, he describes elites living within large houses, with portions of the house having a roof made of roof tiles, while commoners had houses made entirely of organic materials (Zhou 2007: 50). Commoner family homes also had few pieces of furniture and used primarily earthenware and organic materials for cooking and serving, with some metal and other materials being imported from China (Zhou 2007: 76). Zhou Daguan's account provides information that can be tested archaeologically, although it is acknowledged that identifying an Angkorian house in the archaeological record is difficult due to the highly perishable natures of the house structure and of the objects within the house.

Despite these complications, we have used several lines of evidence to identify areas of occupation and habitation, including hearths, garbage pits, ceramics associated with cooking and storage, and plant and animal remains. LiDAR technology allowed us to very efficiently and comprehensively identify landscape features (in particular occupation mounds) that indicate habitation, even in areas covered by dense vegetation, which in turn has allowed for more targeted ground investigations. Our work has focused on excavations of artifact assemblages and feature configurations, which was more effective in sampling subsurface patterning across the enclosure while minimizing destruction of the archaeological record. This method differs from previous excavations of occupation contexts that have largely relied on long trenches (Bâty et al. 2014; Heng et al. 2005; Pottier and Chhem 2008).

\section{2 and 2014 Excavations at Ta Prohm}

The objective of the 2012 field season at Ta Prohm was to test the hypothesis that mounds within the temple enclosure were areas of occupation by identifying artifacts and features associated 
with domestic activities, and to date the occupational history within the enclosure. Ten $1 \times 2 \mathrm{~m}$ trenches were excavated in 2012, focusing on the easternmost portion of a linear east-west mound in an unforested part of the enclosure (FIGURE 3). Based on the surface ceramics, we hypothesized that the mound was the primary area of habitation, while adjacent to it was a lower linear feature that may have served as a path.

The 2014 field season took advantage of available LiDAR data (Evans et al. 2013) to excavate $101 \times 2 \mathrm{~m}$ trenches in different locations across the eastern half of the temple enclosure (FIGURE 3). The LiDAR data clarified the grid system of major features (mounds, depressions or ponds, and linear features or roads) within the enclosure. We have largely assumed that depressions found in various shapes throughout the enclosure were ponds. A preliminary coring program has suggested that they did hold water, although perhaps only seasonally. It also facilitated the identification of a variety of mound-depression configurations, which we have categorized into four different types summarized in Figure 4. The identification of these mounddepression configurations with LiDAR guided our sampling, as we placed trenches within the different mound-depression types across the eastern half of the enclosure. This allowed us to test if the various configurations were all used for habitation and to better understand the nature and timing of occupation within the Ta Prohm enclosure. Our research methodology within these first two field seasons relied on $1 \times 2 \mathrm{~m}$ trenches to verify that the temple enclosure space was used for habitation, and how the timing and nature of this habitation might vary across the enclosure. Future planned work will undertake larger horizontal excavations in order to more closely investigate a household and the spatial distribution of household activities.

\section{Preliminary occupational history at Ta Prohm}

Based on two seasons of fieldwork, we propose the following four-phase occupational history at Ta Prohm.

\section{PHASE I}

We date the lowest layers in our trenches to the 8-10th centuries A.D. based on several lines of evidence. Firstly, our sole radiocarbon date from this phase (TPRM2014 14027.16.01) (FIGURE 5) falls within the 8-10th centuries A.D. Secondly, these layers contained primarily earthenware ceramics and lacked both Song Dynasty (960-1279 A.D.) Chinese tradeware ceramics and Khmer Brown Glazed ceramics, which were not produced until the end of the 10th century (Groslier 1981: 23). Lastly, epigraphic evidence from the first half of the 9th century describes land use near the temple of Pre Rup, just east of Ta Prohm (Pottier 1999: 183). Together, this evidence suggests habitation in the landscape in the area around what would become the Ta Prohm temple enclosure, prior to the temple's construction. Our limited excavations $(1 \times 2 \mathrm{~m}$ trenches) make further discussion on the nature of this habitation difficult at this time.

\section{PHASE II}

We associate the Phase II occupation with the construction of the grid system, which included mounds and linear road features within the temple enclosure. This is part of a broader pattern of orthogonally arranged space within the temple enclosures of the urban core, in which the inhabitants reorganized the landscape into a grid system of mounds, depressions, and linear pathways (Evans et al. 2013: 12596). Some artifact patterning suggests that residential functions were most intense during this phase. Figure 6 presents the quantities of ceramics observed in one particular trench (Trench 15), demonstrating the dramatic increase in the 
number of ceramics, especially earthenware and unglazed stoneware, in Phase II. Our 2012 excavations placed this tentatively within the 12-13th centuries based on the presence of Chinese tradewares, such as Qingbai ceramics.

Our 2014 excavations suggest that in other parts of the eastern enclosure, there were actually two sequences of mound-depression grid construction. Phase IIa refers to the mound construction on top of the original habitation layers or sterile soil that was part of creation of the grid system within the temple enclosure. Several trenches $(11,12,14,15$, and 16) contained ceramics concentrations that represent habitation (FIGURE 7C, D).

In 2014, we identified several trenches that showed additional modification to the mounds, which we refer to as Phase IIb. In many mounds, this consisted of a compacted layer of sandstone or laterite chips, which we suggest may be by-products from the construction of the temple that were recycled into the mound construction. Materials used to build up the mounds vary across the site. Trenches 11 and 12 were cut into a linear mound that may have been constructed using earth excavated during temple moat construction. Trench 14's mound and portions of the linear mound excavated in 2012, located farther east within the temple enclosure, were built up with sand that was brought into this part of the enclosure. The Trench 16 mound was constructed using laterite. Charcoal that was taken from these sandstone chip layers was radiocarbon dated from the early 11 th to early 13 th centuries A.D. (FIGURE 5).

\section{PHASE III}

Phase III occupation intermingles with and lies atop the Phase IIb surface. We believe this habitation dates to the 12-14th centuries and was associated with post-temple construction habitation on the mounds. Ceramics included Khmer Green and Brown glazed stonewares, Song and Yuan Dynasty Chinese tradewares, and earthenware ceramics. Trenches 13, 15, and 16 show evidence for intensive mound use and modification during this phase. During the 2012 field season, we identified a hearth in Trench 5 and a trash pit in Trench 2, which included a sandstone spice mortar and broken cooking vessels (FIGURE 8).

\section{PHASE IV}

The Phase IV occupation is associated with the uppermost layers of the trenches. In 2012, no post-Jayavarman VII period ceramics were recovered, leading to the preliminary conclusion that the northeastern portion of the enclosure was not in use after the 13th century. However, our 2014 excavations did find evidence for some 14th century Yuan Dynasty celadon in Trenches 12 and 15. A 13th-14th century radiocarbon date (TPRM2014 12006S.16.02) was taken from the upper layers of Trench 12, which was also associated with increased quantities of ceramics. Such patterns suggest that people used the mounds, particularly mounds located close to the temple, until at least the 14th century. No evidence for post-14th century ceramics was found in any of the 20 excavation trenches.

\section{Discussion}

Ta Prohm is a useful case study for understanding Angkorian urban structure using multiple archaeological approaches. Our fieldwork data, based primarily on low quantities of ceramics, suggests that there was sparse habitation during Phase I across parts of the Ta Prohm enclosure area by at least the 8th-10th centuries. Epigraphic evidence mentions habitation in the area surrounding Ta Prohm during this time period. That the Ta Prohm temple enclosure was built on previously occupied land is also suggested in the Ta Prohm inscription (K. 273 stanza 35), which 
states that Jayavarman VII founded Rajavihara on land seized by the strength of his arms (Bhadri 2007: 51; Coedès 1906: 74; Maxwell 2007: 31). The dedicatory stele's inauguration date of 1186 A.D. (just 5 years after King Jayavarman VII's ascension) suggests a short construction period for this temple enclosure. This factor would tightly date our Phase II to only 5 years and our Phase III and Phase IV between A.D. 1186 to A.D. 1400, which places the operation of the Ta Prohm enclosure at approximately 200 years.

LiDAR data combined with our excavations suggest that some portions of the enclosure were used more intensively and/or were the focus of more labor expenditure than others. If mounds can accurately be used as a proxy for habitation, the southeastern quadrant made up largely of the mound-depression grid pattern Type 1 contains the densest concentration of mounds and depressions. Excavations within this portion of the grid also suggest multiple modifications of the mounds. Conversely the trenches on the linear mound to the north of Ta Prohm temple contained little evidence for additional mound modification after the initial construction phase. However, other mound-depression patterns located elsewhere within the enclosure, such as the mound-depression grid pattern Type 2 and the multi-shape mounddepression pattern, point towards a less dense habitation, with larger depressions, fewer numbers of individual ponds, and narrower mounds. There are multiple possible factors for this variation in the mound/habitation patterns. The disparity could be due to autonomy in how people were modifying their living areas; differences in landholding rights; or portions of the enclosure that may have housed visitors, pilgrims, or less permanent residents. Further work is needed to better determine the range of functions and use of mounds within the enclosure.

Combined LiDAR, excavation, and documentary evidence have implications for estimating the total population that lived within the enclosure. If habitation was limited to the elevated mound areas, this would restrict the number of individuals who could live inside the enclosure space, especially as we hypothesize that some of the mounds within the multishape mound-depression type do not have strong evidence for habitation. Zhou (2007) mentions that two to three families shared a pond. Evans and Fletcher (2015: 1408) count 125-130 features they interpret as ponds at Ta Prohm, and estimating approximately 5 people within a family, suggest a population of 1800-2000 people. We agree that the actual population within the enclosure may number between 1400-2000 people and hypothesize that many might have lived specifically within the more densely mounded southeastern quadrant. Inscriptional data from Ta Prohm and elsewhere at Angkor list a variety of personnel that may have resided within the enclosure (Lustig and Lustig 2013). However, determining the identities of the residents of Ta Prohm will require the discovery of well-defined activity areas.

\section{Comparison with Residential Spaces Within the Angkor Wat Enclosure}

Our investigation of the temple enclosure of Ta Prohm builds on our previous work within the temple enclosure of Angkor Wat (Stark et al. 2015). We selected these two temples for investigation because their enclosure spaces were relatively undisturbed, and also because they had long and complex histories (Angkor Wat) or textual descriptions indicating intensive occupation (Ta Prohm) that we hypothesized would produce substantial occupational deposits. In both cases, fieldwork was begun prior to acquisition of LiDAR data. Subsequent field seasons used LiDAR data to reveal patterning across the temple enclosures, to guide our sampling (discussed above), and to link our excavations with neighboring areas we were unable to study in the field. Comparison of these two temples provides an opportunity to explore similarities and 
differences in the organization and occupation of temple enclosures during the rule of two of Angkor's most prominent kings. The temple of Angkor Wat was constructed prior to Ta Prohm, by the King Suryavarman II in the early 12th century, and has a longer occupation history than Ta Prohm. Although initially built to honor the god Visnu, it was transformed into a Buddhist temple between the 14th and 16th centuries A.D. (Polkinghorne et al 2013; Thompson 1997). The temple also saw repeated modifications, upkeep, and visitors until the arrival of the French in the 19th century (Thompson 1997, 2000).

Three field seasons $(2010,2013$, and 2015) of excavation have thus far taken place within the Angkor Wat temple enclosure as part of GAP's mission of investigating residential spaces (Carter 2015; Stark et al. 2015). Comparing fieldwork results from these excavations with Ta Prohm elucidates both similarities in the nature of Angkorian temple-enclosure habitation and differences that may reflect the amount of state control or involvement in the construction of residential spaces.

The temple enclosure grid system

As at Ta Prohm, recent LiDAR survey data clarified the grid system within the Angkor Wat enclosure, as well as how landscape organization extended outside the enclosure boundaries (Evans and Fletcher 2015; Stark et al. 2015). At both temple enclosures, we see orthogonally arranged linear features (roads) that extend throughout the enclosure. Additionally, at both sites, residential space surrounds the temples and consists of a series of patterned mounds and depressions. At Ta Prohm, there are a series of different mound-depression pattern types (FIGURE 4); however, at Angkor Wat, there is a more formal grid system dividing the space into a series of 60 cells, each of which was sub-divided into a series of four mounds and many of which also contained four depressions. More recent modification to the western portion of the Angkor Wat enclosure has obscured this pattern somewhat; however, we argue that when originally constructed, the enclosure initially contained 283 mounds and 250-300 depressions (Stark et al. 2015). Each individual mound measures approximately $25 \times 38 \mathrm{~m}$, which is generally larger than the mound space at Ta Prohm. However, further investigations are needed to determine if each mound at Angkor Wat held a single household or multiple households.

\section{Phases of occupation and mound construction}

Excavations suggest that the landscape around the Angkor Wat temple was extensively reorganized before or during the construction of the temple itself, including both space inside and east of the moat; geometric spiral features were also recorded just south of the complex (Evans and Fletcher 2015; Stark et al. 2015). At Angkor Wat, the construction of the mounddepression grid system and subsequent habitation dates largely to the 11-13th centuries A.D., with ceramic and radiocarbon dates from the uppermost layers dating from the 15-17th centuries A.D. (FIGURE 5) (Stark et al. 2015).

Our excavations did not show evidence for additional modification of the mounds following their initial construction. Additionally, mounds were largely constructed of soil and lacked the thick floors or foundations made of stone chips as seen at Ta Prohm. We note that this is unusual given the longer period of habitation at the site and contrasts with Ta Prohm, in which multiple mound-depression shapes were constructed using a variety of materials and in some cases involved multiple modifications of mounds.

\section{Ceramics and intensity of habitation}


A consideration of the ceramics at both sites sheds light on the intensity of occupation. Figure 9 shows a count of the different ceramic types found at both sites. The proportions of different types of ceramics are roughly similar, with earthenware and glazed and unglazed Khmer stonewares being the most predominant types found at both sites. The most notable difference between the two sites is the quantity of ceramics found. A total of $135 \mathrm{~kg}$ of ceramics and roof tiles were excavated over two field seasons from the 20 trenches $\left(79.12 \mathrm{~m}^{3}\right.$ or a sherd density of $1.71 \mathrm{~kg} / \mathrm{m}^{3}$ ) at Ta Prohm. Conversely, only $46.5 \mathrm{~kg}$ of ceramics were uncovered from two field seasons at Angkor Wat, despite excavating a greater volume ( 33 trenches, ca. $89.6 \mathrm{~m}^{3}$ or a sherd density of $.52 \mathrm{~kg} / \mathrm{m}^{3}$ ) in residential locations. This difference is also notable considering the longer period of occupation at Angkor Wat.

There are several potential reasons for this discrepancy. The Ta Prohm inscription implies that a large number of the people who serviced the temple may have lived and worked within the temple enclosure. The higher quantity of ceramics at Ta Prohm may reflect a greater density of use and occupation at this temple site than at Angkor Wat. The seemingly light occupation at Angkor Wat may also be related to the possibility that mounds within the enclosure were not inhabited year-round or experienced some seasonality in their use (Stark et al. 2015: 1451-1452). We must also consider that there may have been different deposition practices in each location due to the different functions performed at each temple. Ta Prohm was constructed by the king as a sprawling ancestral shrine, monastery, and institute of learning; Angkor Wat, on the other hand, was constructed as the central state pyramid-temple of King Suryavarman II. It is possible the different functions of each of these temples carried with it different ideas regarding cleanliness within these spaces. Furthermore, the uniformity of the grid system suggests seemingly greater state control at Angkor Wat, which may also point towards more organized garbage disposal practices at this location. Or there simply may have been a shift in waste management practices over time (Arnold 2015). Further research is needed to address this question in more depth.

\section{Temple Enclosures as Residential Spaces: Concluding Discussion}

Our fieldwork has demonstrated that, as has long been speculated, open areas surrounding temples were residential spaces. At both Ta Prohm and Angkor Wat, the landscape was extensively transformed to create an orthogonal grid system of temples and the surrounding space in their enclosures. In both cases, the grid system extended outside the exterior enclosure wall surrounding the temple sites. At Ta Prohm, there is limited evidence for sparse pre-11th century habitation that was transformed and modified into the mound-depression grid system in association with the construction of the stone temple in the late 12th century A.D. In contrast, there is no clear evidence that the landscape around Angkor Wat was intensively inhabited prior to temple construction (although see Sonnemann and colleagues [2015] for discussion of the western portion of Angkor Wat).

These temple enclosures were high-density residential zones within a broader, often dispersed, agricultural landscape. Scholars have previously estimated Angkor's total population at 750,000 people within a $1000 \mathrm{~km}^{2}$ area (Fletcher et al. 2003: 116), placing the overall population density at 750 persons per $\mathrm{km}^{2}$. We have estimated a population of 1400-2000 people living within mounded areas of the 68 hectare enclosure at Ta Prohm. Omitting the 5 ha stone temple complex produces a population density within the enclosure of 882-1260 persons per 
$\mathrm{km}^{2}$. Similarly, we have previously estimated the population on the mounds within the fourth enclosure of Angkor Wat $(1000 \times 815 \mathrm{~m})$ to be between 3000-4300 people (Fletcher et al. 2015; Stark et al. 2015), or 2445-3505 persons per km ${ }^{2}$. The walled city of Angkor Thom, with an estimated population of 16,000 inhabitants at its peak (Hanus and Evans 2016: 91), had a population density of ca. 1778 persons per $\mathrm{km}^{2}$. The occupation within temple enclosures highlights the variability of settlement organization within the Greater Angkor region.

Excavations within Ta Prohm and Angkor Wat also add valuable archaeological data to our understandings of Angkorian and Early Modern (15th-18th centuries A.D.) Southeast Asian urbanism, which have largely relied on historic documents and observations of large-scale features (Stark 2015). Data from other Southeast Asian cities reveal variations on a dispersed settlement pattern. For example, Indonesian cities have been described as "agro-urban," with a dispersed settlement pattern (Miksic 1989). Others have emphasized the semi-urban nature of cities like Srivijaya, which had urbanized pockets of dense population, surrounded by a hinterland (Kulke 1991: 12). Christie (1991: 25) has described Javanese states as being made up of "a densely populated rural landscape." In contrast, densely populated urban centers do not become more common until the Early Modern period and are associated with polities participating in maritime trade (Reid 1980, 1993). Even then, foreign visitors to these Early Modern cities noted "the boundary between city and countryside seemed almost non-existent" (Reid 1980: 240). Angkor, which had a dispersed rural settlement pattern as well as pockets of high-density zones around temples and within Angkor Thom, provides another example of urban organization within Southeast Asia.

Despite the centralized planning reflected in the grid systems around the temples, the internal organization in both locations was quite different. Perhaps this was related to the functions of each temple, as Angkor Wat was the central state temple of Suryavarman II, while Ta Prohm fulfilled quite different roles, was one of several temple constructions by Jayavarman VII, and occupied a somewhat peripheral position beyond the formally-enclosed city center of Angkor Thom. Ta Prohm's inscriptional evidence notes students and teachers and perhaps others associated with the ritual functions of the temple as residents. We do not have similar inscriptional evidence for Angkor Wat; therefore, it is unclear who may have lived in the temple residential space or their relationship to the ritual functions of the temple. The density of ceramics, with Ta Prohm having higher quantities of ceramics than Angkor Wat, also points towards different use of residential space in each location that again may be related to the ritual functions of the temple and those who lived in the enclosure.

The decrease in the occupation density of the residential space varied within both locations as well. Radiocarbon and ceramic data suggest that Ta Prohm was depopulated by the 14th century, coinciding with a period of socio-political and climatic changes that led to the decline of the Angkorian elite socio-political structure by the early 15th century A.D. (Buckley et al. 2010, 2014; Coedès 1968; Vickery 2004). Conversely, the use of the Angkor Wat temple and residential space around the temple continued into the Post-Angkorian period (Stark et al. 2015). The entire landscape of Angkor was not abandoned during the Post-Angkorian period, although portions of this landscape, like that at Ta Prohm, fell out of use.

Temple enclosures were intentionally planned spaces made up of residents who would have encountered one another daily within residential spaces and perhaps within the confines of the temple as part of their occupational or ritual duties. Temples also likely brought together large numbers of non-resident worshippers or pilgrims who periodically visited the ritual spaces of the temple as well. In the dispersed low-density landscape of Greater Angkor, temple 
enclosures were high-density nodes. Careful excavation of habitation areas combined with LiDAR data has allowed us to identify these habitation areas and situate them within the larger grid system and landscape patterning of Greater Angkor.

\section{Acknowledgements}

We wish to thank the APSARA National Authority for their collaboration and permission to undertake excavations within the Ta Prohm enclosure. We thank So Malay and Martin King for administrative support, and GAP 2012 and 2014 crew members, whose labor produced this research. We thank the PT McElhanney, Indonesia company for its contribution to the LiDAR acquisition, which was funded by eight institutions: the Khmer Archaeology LiDAR Consortium (KALC), APSARA National Authority, the University of Sydney, the École française d'Extrême-Orient, Société Concessionaire d'Aéroport, the Hungarian Southeast Asian Research Institute, Japan-APSARA Safeguarding Angkor, the Archaeology and Development Foundation, and the World Monuments Fund. Damian Evans' contribution to this project is funded by the European Research Council (ERC) under the European Union's Horizon 2020 research and innovation program (grant agreement No 639828). This work was supported by the Australian Research Council under grant DP1092663. We also wish to thank The Robert Christie Foundation. We are indebted to Drs. Mitch Hendrickson and Michael E. Smith for providing invaluable comments on earlier drafts and Christophe Pottier for his insights on Angkorian urbanism. All mistakes are the responsibility of the principal author.

\section{Notes on Contributors}

Alison Kyra Carter (Ph.D. 2013, University of Wisconsin-Madison) is an Assistant Professor in the Department of Anthropology at the University of Oregon. Her doctoral research focused on trade and exchange of glass and stone beads within mainland Southeast Asia during the Iron Age period. Her current project is focused on household archaeology during the Angkorian period.

Piphal Heng (Ph.D. 2018, University of Hawai'i at Mānoa) did his doctoral research focused on pre-Angkorian settlement patterns, economy and politics, and his Cambodian archaeology interests also include Angkorian and post-Angkorian political economy.

Miriam Stark (Ph.D. 1993, University of Arizona) is a Professor in the Department of Anthropology at the University of Hawai'i at Mānoa. Her research focuses primarily on Cambodian archaeology and covers themes related to urbanism, residential patterning, landscape ecology, political economy, and ceramics.

Rachna Chhay (B.A. 2002, Royal University of Fine Arts, Phnom Penh) is a research archaeologist with APSARA National Authority (Kingdom of Cambodia). His research focuses primarily on Angkorian economics, with a particular emphasis on craft production and consumption (stoneware ceramics) and on agriculture.

Damian Evans (Ph.D. 2007, University of Sydney) is a Research Fellow at the French Institute of Asian Studies (EFEO). His work revolves around using advanced geospatial technologies for mapping and analyzing archaeological landscapes. His current project uses airborne laser scanning or LiDAR methods for a large-scale comparative investigation of early urbanism in Southeast Asia. 


\section{References}

Arnold, F. 2015. "Clean and Unclean Space: Domestic Waste Management at Elephantine.” In Household Studies in Complex Societies: (Micro) Archaeological and Textual Approaches, edited by M. Müller, 151-168. Chicago: University of Chicago Press.

Bâty, P., and A. Bolle. 2005. "Sanctuaires Et Habitats Sous L'aeroport De Siem Reap." Archeologia 427: 18-23.

Bâty, P., A. Desbat, F. Sellami, and S. Marquié. 2014. "Le Tertre E à Trapeang Ropou: Approche Archéologique et Géomorphologique d'un Habitat Angkorien."Aséanie 33: 331-387.

Bhadri, K. M. 2007. "Ta Prohm Inscription of Jayavarman VII, AD 1186.” In Ta Prohm: A Glorious Era in Angkor Civilization, edited by P. K. Kapur and S. Sahai, 49-56. Bangkok: White Lotus Press.

Briggs, L. 1951. "The Ancient Khmer Empire." Transactions of the American Philosophical Society New Series 41 (1): 1-295.

Bruguier, B. 1998. 'L'organisation spatiale des sanctuaires khmers: plan axé ou concentrique?" In Southeast Asian Archaeology 1994, edited by P.-Y. Manguin, 173-178. Hull, U.K.: University of Hull Centre for Southeast Asian Studies.

Buckley, B. M., K. J. Anchukaitis, D. Penny, R. Fletcher, E. R. Cook, M. Sano, L. C. Nam, A. Wichienkeeo, T. T. Minh, and T. M. Hong. 2010. "Climate as a Contributing Factor in the Demise of Angkor, Cambodia." Proceedings of the National Academy of Sciences 107: 67486752.

Buckley, B. M., R. Fletcher, S. S. Wang, B. Zottoli, and C. Pottier. 2014. "Monsoon Extremes and Society Over the Past Millennium on Mainland Southeast Asia." Quaternary Science Reviews 95: 1-19.

Carter, A. K. 2015. “Angkor Wat Enclosure: June-July 2015 Greater Angkor Project 2011-2015 Preliminary Report Series." Report on file with the APSARA National Authority, Siem Reap, Cambodia.

Carter, A., P. Heng, S. Heng, and K. Phon. 2014. "Archaeology in Post-Khmer Rouge Cambodia." In Encyclopedia of Global Archaeology, edited by C. Smith, 6059-6065. New York: Springer.

Christie, J. W. 1991. "States without Cities: Demographic Trends in Early Java.” Indonesia 52: 23-40.

Coe, M. D. 1957. "The Khmer Settlement Pattern: A Possible Analogy with that of the Maya." American Antiquity 22: 409-410. 
Coedès, G. 1906. "La Stèle de Ta-Prohm.” Bulletin de l'École française d'Extrême-Orient 6: 4485 .

Coedès, G. 1941. "La Stèle de Práh Khan d'Angkor.” Bulletin de l'École française d'ExtrêmeOrient 41: 255-302.

Coedès, G. 1968. The Indianized States of Southeast Asia. Honolulu: East-West Center Press.

Coedès, G., and P. Dupont. 1943. "Les Stèles de Sdǒk Kak Thom Phnom Sandak et Práah Vihār." Bulletin de l'Ecole française d'Extrême-Orient 43: 56-154.

Cowgill, G. L. 2004. "Origins and Development of Urbanism: Archaeological Perspectives.” Annual Reviews in Anthropology 33: 525-549.

Cunin, O. 2013. "A Study of Wooden Structures: A Contribution to the Architectural History of the Bayon Style Monuments." In Materializing Southeast Asia's Past: Selected Papers from the 12th International Conference of the European Association of Southeast Asian Archaeologists, Volume 2, edited by M. Klokke and V. Degroot, 82-107. Singapore: NUS press.

Evans, D. 2007. 'Putting Angkor on the Map: A New Survey of a Khmer 'Hydraulic City' in Historical and Theoretical Context.” Ph.D. diss., University of Sydney.

Evans, D., and R. Fletcher. 2015. "The Landscape of Angkor Wat Redefined." Antiquity 89: $1402-1419$.

Evans, D., R. J. Fletcher, C. Pottier, J. B. Chevance, D. Soutif, B. S. Tan, S. Im, D. Ea, T. Tin, S. Kim, C. Cromarty, S. De Greef, K. Hanus, P. Bâty, R. Kuszinger, I. Shimoda, and G. Boornazian. 2013. "Uncovering Archaeological Landscapes at Angkor using LiDAR." Proceedings of the National Academy of Sciences 110: 12595-12600.

Evans, D., C. Pottier, R. J. Fletcher, S. Hensley, I. Tapley, A. Milne, and M. Barbetti. 2007. “A Comprehensive Archaeological Map of the World's Largest Preindustrial Settlement Complex at Angkor, Cambodia." Proceedings of the National Academy of Sciences 104: 14277-14282.

Filliozat, J. 1951. "Le Symbolisme du Monument du Phnom Bàkhèn.” Bulletin de l'Ecole française d'Extrême-Orient 44: 527-554.

Fisher, K. D., and A. T. Creekmore, III. 2014. "Making Ancient Cities: New Perspectives on the Production of Urban Places." In Making Ancient Cities: Space and Place in Early Urban Societies, edited by A. T. Creekmore, III and K. D. Fisher, 1-31. New York: Cambridge University Press.

Fletcher, R. 2000-2001. "Seeing Angkor: New Views on an Old City." The Journal of the Oriental Society of Australia 32-33: 1-27. 
Fletcher, R. 2009. "Low-Density, Agrarian-Based Urbanism: A Comparative View." Insights 2: $2-20$.

Fletcher, R. 2012. "Low-Density, Agrarian-Based Urbanism: Scale, Power and Ecology." In The Comparative Archaeology of Complex Societies, edited by M. E. Smith, 285-321. Cambridge: Cambridge University Press.

Fletcher, R. J., M. Barbetti, D. Evans, H. Than, I. Sokrithy, K. Chan, D. Penny, C. Pottier, and T. Somaneath. 2003. "Redefining Angkor: Structure and Environment in the Largest, Low Density Urban Complex of the pre-Industrial World." Udaya 4: 107-121.

Fletcher, R., D. Evans, C. Pottier, and R. Chhay. 2015. "Angkor Wat: An Introduction.” Antiquity 89: 1388-1401.

Fletcher, R., D. Penny, D. Evans, C. Pottier, M. Barbetti, M. Kummu, and T. Lustig. 2008. "The Water Management Network of Angkor, Cambodia." Antiquity 82: 658-670.

Fletcher, R., and C. Pottier. 2002. "The Gossamer City: A New Inquiry." Museum International 54 (1-2): 23-27.

Fletcher, R. C. Pottier, D. Evans, and M. Kummu. 2008. "The Development of the Water Management System of Angkor: A Provisional Model." Bulletin of the Indo-Pacific Prehistory Association 28: 57-66.

Gaucher, J. 2002. “The City of Angkor. What is it?” Museum International 54 (1-2): 28-36.

Gaucher, J. 2003. "New Archaeological Data on the Urban Space of the Capital City of Angkor Thom." In Fishbones and Glittering Emblems: Southeast Asian Archaeology 2002, edited by A. Karlstrom and A. Kallen, 233-242. Stockholm: Museum of Far Eastern Antiquities.

Gaucher, J. 2004. “Angkor Thom, une Utopie Réalisée? Structuration de l'Espace et Modèle Indien d'Urbanisme dans le Cambodge Ancien." Arts asiatiques 59: 58-86.

Groslier, B. P. 1956. Angkor: Hommes et Pierres. Paris: Arthaud. Groslier, B. P. 1974.

“Agriculture et Religion Dans l'Empire Angkorien.” Études rurales 53-56: 95-117.

Groslier, B. P. 1979 "VII. La Cité Hydraulique Angkorienne: Exploitation ou Surexploitation du sol?" Bulletin de l'Ecole française d'Extrême-Orient 66 (1): 161-202.

Groslier, B. P. 1981 "Introduction to the Ceramic Wares of Angkor." In Khmer Ceramics: 9th14th Century, edited by D. Stock, 9-39. Singapore: Southeast Asia Ceramics Society.

Groslier, B. P., C. Pottier, and T. Lustig. 2007. "The Angkorian Hydraulic City." Aseanie 20: 133-140. 
Hanus, K., and D. Evans. 2016. "Imaging the Waters of Angkor: A Method for Semi-Automated Pond Extraction from LiDAR Data." Archaeological Prospection 23: 87-94.

Hawken, S. 2007. “Angkor: Sprawling Forms of a Medieval Metropolis-Research in Cambodia Help Explain Low-Density Cities.” Topos 61: 90-96.

Hawken, S. 2013. "Designs of Kings and Farmers: Landscape Systems of the Greater Angkor Urban Complex." Asian Perspectives 52: 347-367.

Hendrickson, M., and D. Evans. 2015. "Reimagining the City of Fire and Iron: A Landscape Archaeology of the Angkor-Period Industrial Complex of Preah Khan of Kompong Svay, Cambodia (ca. 9th to 13th Centuries A.D.)." Journal of Field Archaeology 40 (6): 644-664.

Heng, T., W. Johnson, S. Mackey, N. Richards, L. Matarese, and S. Hoppe. "Tumnup Barang: January-February 2005." Report on file with the APSARA National Authority, Siem Reap, Cambodia.

Henriksen, M. A. 1982. "The First Excavated Prehistoric House Site in Southeast Asia." In The House in East and Southeast Asia: Anthropological and Architectural Aspects, edited by K. Izikowitz and P. Sorensen, 17-24. Richmond: Curzon Press.

Isendahl, C. 2012. "Agro-Urban Landscapes: The Example of Maya Lowland Cities." Antiquity 86: $1112-1125$.

Jacques, C. 1978. "VI. Études d'Épigraphie Cambodgienne. XL Autour de Quelques Toponymes de l'Inscription du Prasat Trapan Run K.598: La Capitale Angkorienne de Yašovarman Ier à Sûryavarman Ier." Bulletin de l'Ecole française d'Extrême-Orient 65 (1): 281-332.

Jacques, C. 1997. Angkor: Cities and Temples. London: Thames \& Hudson. Jacques, C. 2007. "The Historical Development of Khmer Culture from the Death of Sūrayarman II to the 16th Century." In Bayon: New Perspectives, edited by J. Clark, 28-49. Bangkok: River Books.

Jacques, C. 2008. "Moats and Enclosure Walls of the Khmer Temples." In Interpreting Southeast Asia's Past: Monument, Image and Text, edited by P. Sharrock, I. C. Glover, and E. A. Bacus, 2-8. Singapore: NUS Press.

Jacques, C., and M. Freeman. 2009. Ancient Angkor. Bangkok: River Books.

Jacques, C., and P. Lafond. 2007. The Khmer Empire: Cities and Sanctuaries from the 5th to the 13th Century. Bangkok: River Books.

Kapur, P. K., and S. Sahai. 2007. Ta Prohm: A Glorious Era in Angkor Civilization. Bangkok: White Lotus Press. 
Klassen, S. 2018. "Adaptive Capacity of the Water Management Systems of Two Medieval Khmer Cities, Angkor and Koh Ker." Ph.D. diss., Arizona State University.

Kulke, H. 1991. "Epigraphical References to the 'City' and the 'State' in Early Indonesia." Indonesia 52: 3-22.

Kummu, M. 2009. "Water Management in Angkor: Human Impacts on Hydrology and Sediment Transportation.” Journal of Environmental Management 90: 1413-1421.

Lucero, L. J., R. Fletcher, and R. Coningham. 2015. "From 'Collapse' to Urban Diaspora: The Transformation of Low-Density, Dispersed Agrarian Urbanism.” Antiquity 89: 1139-1154.

Lustig, E., and T. Lustig. 2013. "New Insights into 'les Interminables Listes Nominatives d'Esclaves' from Numerical Analyses of the Personnel in Angkorian Inscriptions." Aséanie 2013: 55-83.

Lustig, T., and E. Lustig. 2015. "Following the Non-Money Trail: Reconciling some Angkorian Temple Accounts." Journal of Indo-Pacific Archaeology 39: 26-37.

Mannikka, E. 1996. Angkor Wat: Time, Space, and Kingship. Honolulu: University of Hawaii Press.

Maxwell, T. S. 2007. "The Stele Inscription of Preah Khan, Angkor.” Udaya, Journal of Khmer Studies 8: 1-114.

Miksic, J. N. 1989. "Urbanization and Social Change: The Case of Sumatra." Archipel 37: 3-29.

Miksic, J. N. 2000. "Heterogenetic Cities in Premodern Southeast Asia." World Archaeology 32: $106-120$.

Mouhot, H. 1864. Travels in the Central Parts of Indo-China Siam, Cambodia, and Laos during the Years 1858, 1859, and 1860. Vol II. London: John Murray.

Osborne, J. F. 2015. "Ancient Cities and Power: The Archaeology of Urbanism in the Iron Age Capitals of Northern Mesopotamia.” International Journal of Urban Sciences 19: 7-19.

Polkinghorne, M., C. Pottier, and C. Fischer. 2013. "One Buddha Can Hide Another.” Journal Asiatique 301: 575-624

Pottier, C. 1999. “Carte Archéologique de la Région d'Angkor. Zone Sud.” Ph.D. diss., L’Universite Paris III.

Pottier, C. 2000. “À la Recherche de Goloupura.” Bulletin de l'École française d'Extrême-Orient 87: 79-107. 
Pottier, C. 2012. "Beyond the Temples: Angkor and its Temple." In Old Myths and New Approaches. Interpreting Ancient Religious Sites in Southeast Asia, edited by A. Haendel, 12 27. Clayton, Victoria, Australia: Monash University Publishing.

Pottier, C., and R. Chhem. 2008. “Á la Découverte d'un Hôpital Angkorien: Résultats Préliminaires d'une Campagne Archéologique au Prasat Tromoung." Udaya, Journal of Khmer Studies 9: 169-182.

Qadeer, M. A. 2000. "Ruralopolises: The Spatial Organisation and Residential Land Economy of High-Density Rural Regions in South Asia." Urban Studies 37: 1583-1603.

Reid, A. 1980. "The Structure of Cities in Southeast Asia, Fifteenth to Seventeenth Centuries." Journal of Southeast Asian Studies 11: 235-250.

Reid, A. 1993. Southeast Asia in the Age of Commerce 1450-1680. Volume Two, Expansion and Crisis. New Haven: Yale University Press.

Roveda, V. 2004. "The Archaeology of Khmer Images." Aséanie 13: 11-46.

Roveda, V. 2005. Images of the Gods: Khmer Mythology in Cambodia, Thailand and Laos. Bangkok: River Books.

Sahai, S. 2012. The Hindu Temples in South East Asia: Their Role in Social Economic and Political Formations. New Delhi: Aryan Books.

Sedov, L. A. 1978. "Angkor: Society and State.” In The Early State, edited by H. J. Claessen and P. Skalnik, 111-130. The Hague: Mouton.

Smith, M. E. 2009. "V. Gordon Childe and the Urban Revolution: A Historical Perspective on a Revolution in Urban Studies." Town Planning Review 80: 3-29.

Smith, M. E. 2010. "The Archaeological Study of Neighborhoods and Districts in Ancient Cities." Journal of Anthropological Archaeology 29: 137-154.

Sonnemann, T. F., D. O'Reilly, R. Chhay, R. Fletcher, and C. Pottier. 2015. "The Buried 'Towers' of Angkor Wat." Antiquity 89 (348): 1420-1438.

Stark, B. L. 2014. "Ancient Open Space, Gardens, and Parks: A Comparative Discussion of Mesoamerican Urbanism.” In Making Ancient Cities: Space and Place in Early Urban Societies, edited by A. T. Creekmore, III and K. D. Fisher, 370-406. Cambridge: Cambridge University Press.

Stark. M. T. 2015. "Southeast Asian Urbanism: From Early City to Classical State." In The Cambridge World History, edited by N. Yoffee, 74-93. Cambridge: Cambridge University Press. 
Stark, M. T., D. Evans, R. Chhay, P. Heng, and A. Carter. 2015. "Residential Patterning at Angkor Wat." Antiquity 89: 1439-1455.

Stark, M. T., and P. B. Griffin. 2004. "Archaeological Research and Cultural Heritage Management in Cambodia's Mekong Delta: The Search for the 'Cradle of Khmer Civilization.", In Marketing Heritage: Archaeology and the Consumption of the Past, edited by Y. Rowan and U. Baram, 117-141. Walnut Creek, CA: Altamira Press.

Stern, P. 1951. "Diversité et Rythme des Fondations Royales Khmères." Bulletin de l'École française d'Extrême-Orient 44: 649-687.

Tainturier, F. 2006. "Building in Wood: Notes on a Vanishing Age-Old Tradition." In Wooden Architecture of Cambodia: A Disappearing Heritage, edited by F. Tainturier, 12-37. Siem Reap: Center for Khmer Studies.

Thompson, A. 1997. "Changing Perspectives: Cambodia after Angkor.” In Sculpture of Angkor and Ancient Cambodia: Millennium of Glory, edited by H. I. Jessup and T. Zephir, 22-32. Washington, D.C.: National Gallery of Art.

Thompson, A. 2000. "Lost and Found: The Stupa, the Four-Faced Buddha, and the Seat of Royal Power in Middle Cambodia." In Proceedings of the 7th International Conference of the European Association of Southeast Asian Archaeologists, Berlin, 31 August-4 September 1998, edited by W. Lobo and S. Reimann, 245-264. Hull, U.K.: Centre for South-East Asian Studies, University of Hull and Ethnologisches Museum, Staatliche Museen zu Berlin Stiftung Preuischer Kulturbesitz.

Vickery, M. 1998. Society, Economics, and Politics in Pre-Angkor Cambodia: The 7th-8th Centuries. Tokyo: Centre for East Asian Cultural Studies for UNESCO, Toyo Bunko.

Vickery, M. 2004. Cambodia and its Neighbors in the 15th Century. Singapore: Asia Research Institute, National University of Singapore. Vickery, M. 2007. "Introduction." In Bayon: New Perspectives, edited by J. Clark, 10-27. Bangkok: River Books.

Wheatley, P. 1971. The Pivot of the Four Quarters: A Preliminary Enquiry into the Origins and Character of the Ancient Chinese City. Chicago: Aldine Publishing Company.

Zhou, D. 2007. A Record of Cambodia: The Land and its People, translated by P. Harris. Chiang Mai, Thailand: Silkworm Books. 


\section{Figures for: Urbanism and Residential Patterning in Angkor}
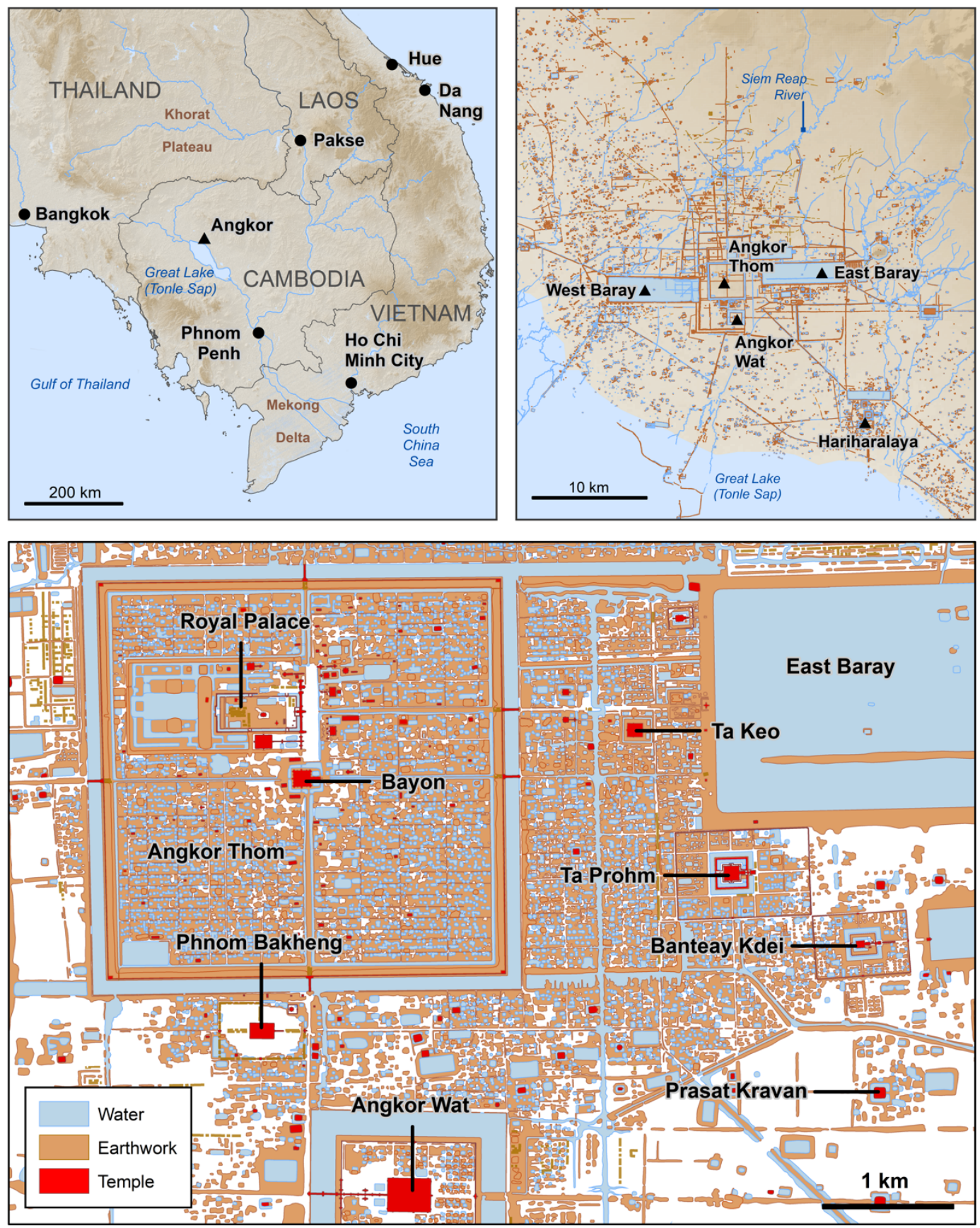

Figure 1. Top left: Regional map of Southeast Asia noting the location of Angkor. Top right: Map of Greater Angkor. Bottom: Interpretation of archaeological features visible within remote sensing data (principally lidar) with important temples in the civic-ceremonial center of Angkor labeled. Mapping by Pelle Wijker, Damian Evans and Christophe Pottier. Figure created by Damian Evans. 
Fifth Enclosure

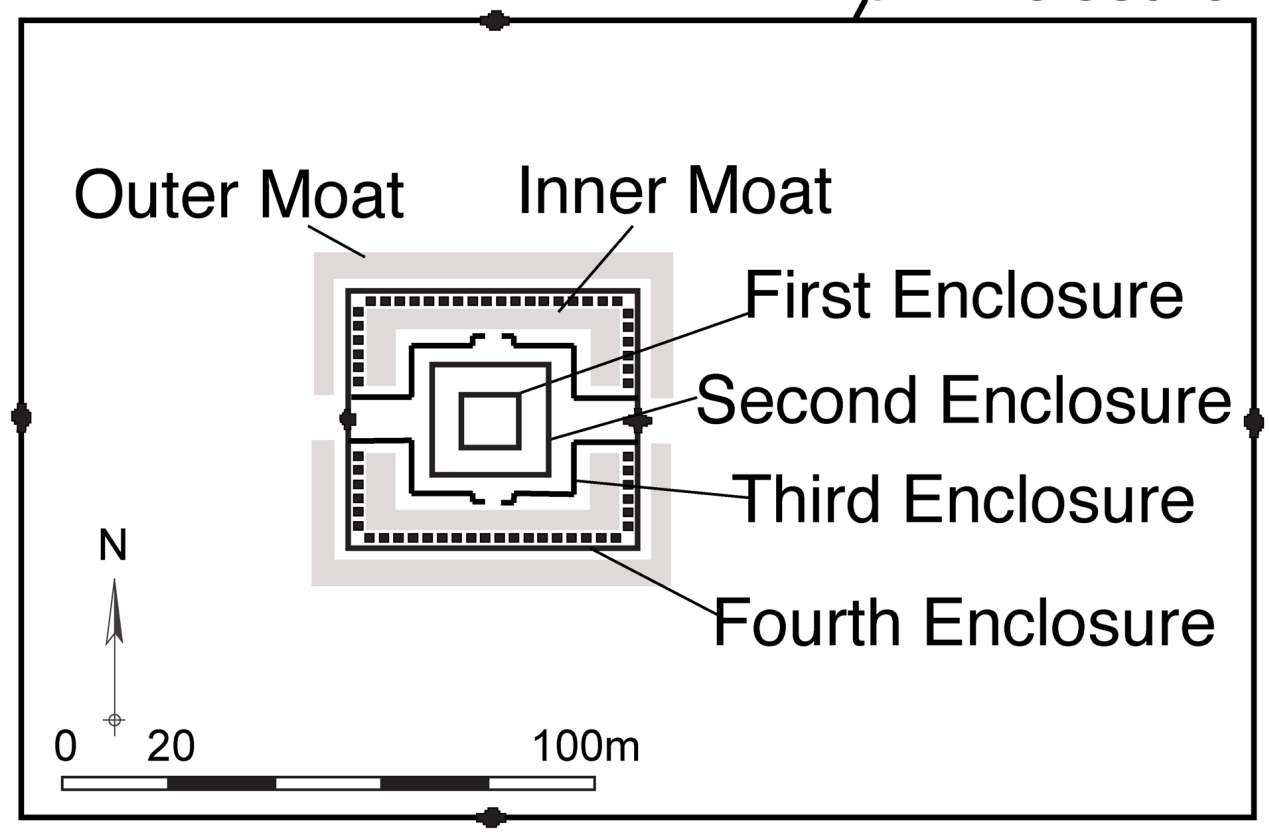

Figure 2: Simplified plan map of Ta Prohm noting the different enclosures. 

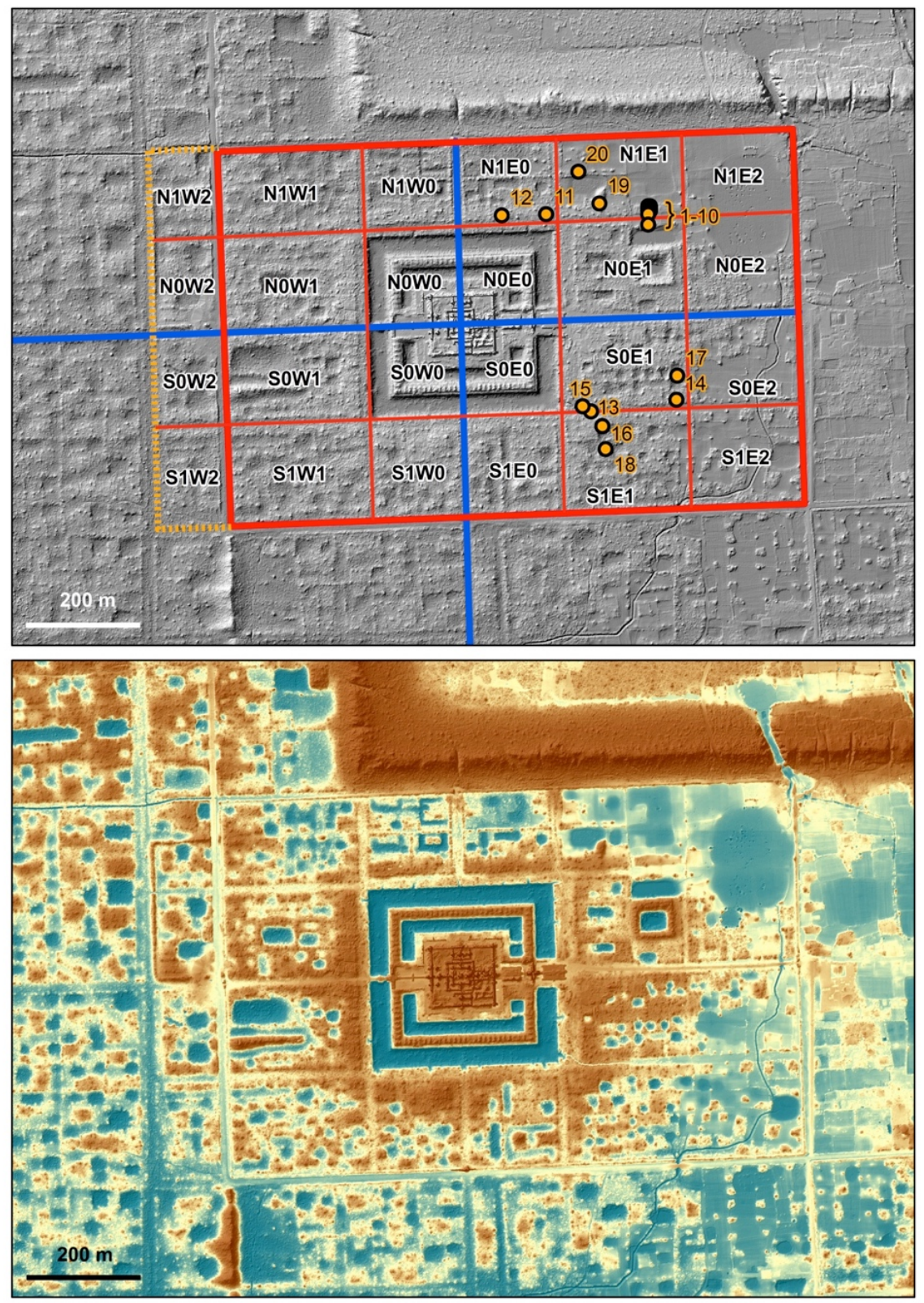

Figure 3: Top: A hill shade model of the Ta Prohm area derived from lidar data (Evans et al 2013) showing the grid pattern and trench locations (orange dots) as described in the text. Trenches 1-10 were excavated in 2012, while trenches 11-20 were excavated in 2014. Bottom: A hill shaded elevation model of the same area depicted in the top panel, enhanced to highlight the spatial patterning of archaeological topography. The linear depressions, which we interpret as roads, radiate out from the central tower of Ta Prohm, where the east-west and north-south axes intersect. From this central point, we interpret that there are two grids that project to the north and south, two grids to the west, and three grids to the east. The red lines in the top image demarcate this internal grid system. Notably, the lidar image demonstrates that the grid system originally extended outside the outer fifth enclosure wall to the west, which is noted by the orange dotted line on the western edge of the temple complex of the top image. 


\begin{tabular}{|c|c|c|c|c|}
\hline $\begin{array}{l}\text { Mound- } \\
\text { Depression Type }\end{array}$ & Description & Location & Trenches & Image \\
\hline $\begin{array}{l}\text { Linear mounds (or } \\
\text { embankments) }\end{array}$ & $\begin{array}{l}\text { Long mounds that extended East- } \\
\text { West in northern part of the } \\
\text { enclosure. Contained two phases of } \\
\text { mound construction, with some } \\
\text { mounds having up to } 3 \mathrm{~m} \text { of mound fill. } \\
\text { Sandstone chips, which may have } \\
\text { been recycled from the construction of } \\
\text { the temple, were also found as part of } \\
\text { the fill. } 2012 \text { excavations identified } \\
\text { hearth and stove fragments (see } \\
\text { Figure } 8 \text { ). }\end{array}$ & $\begin{array}{l}\text { Northern part of } \\
\text { the enclosure }\end{array}$ & $\begin{array}{l}\text { All } 2012 \text { Trenches } \\
(1-10) \\
\text { Trenches 11, 12, and } \\
19\end{array}$ & Example of linear mounds in $\mathrm{NE}$ quadrant \\
\hline $\begin{array}{l}\text { Mound- } \\
\text { Depression Grid } \\
\text { Pattern Type } 1\end{array}$ & $\begin{array}{l}\text { Multiple rows of roughly square } \\
\text { depressions and discrete mounds. } \\
\text { Similar to a habitation pattern found } \\
\text { within the walled city of Angkor Thom } \\
\text { and the Angkor Wat enclosure. } \\
\text { Habitation and construction } \\
\text { sequences similar to as linear } \\
\text { mounds. }\end{array}$ & $\begin{array}{l}\text { Southeastern } \\
\text { quadrant (grids } \\
\text { SOE1, S0E2, and } \\
\text { S1E1). }\end{array}$ & $\begin{array}{l}\text { Trenches } 13,14,15 \text {, } \\
16,17 \text {, and } 18)\end{array}$ & 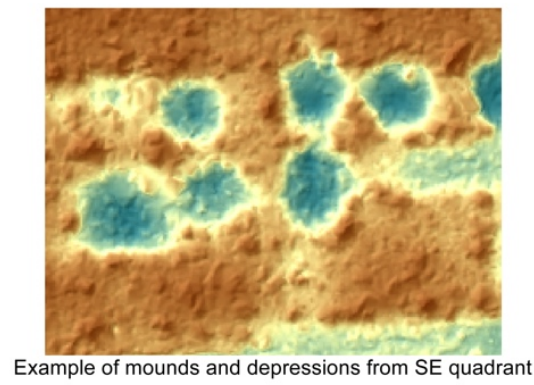 \\
\hline $\begin{array}{l}\text { Mound- } \\
\text { Depression Grid } \\
\text { Pattern Type } 2\end{array}$ & $\begin{array}{l}\text { Mounds and square depressions } \\
\text { similar to the Type } 1 \text { patter, but with } \\
\text { depressions being larger and more } \\
\text { rectangular, including some with } \\
\text { embankments. These mounds were } \\
\text { not sampled; habitation and } \\
\text { construction sequences unknown. }\end{array}$ & $\begin{array}{l}\text { East and west of } \\
\text { the temple in } \\
\text { grids NOE1, } \\
\text { NOW1, and } \\
\text { SOW1. }\end{array}$ & None & 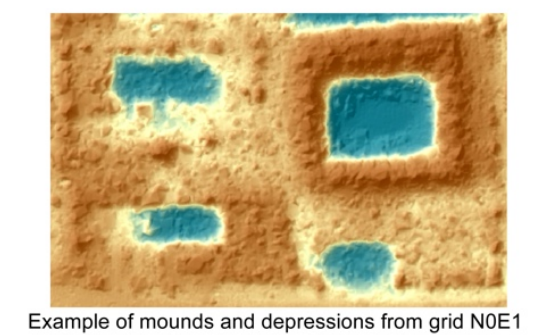 \\
\hline $\begin{array}{l}\text { Multi-shaped } \\
\text { Mound- } \\
\text { Depression } \\
\text { Pattern }\end{array}$ & $\begin{array}{l}\text { Irregularly shaped mounds and } \\
\text { depressions that form geometric } \\
\text { designs. Fewer artifacts and no } \\
\text { hearth or trash pit features compared } \\
\text { to other mound-depression } \\
\text { configurations. }\end{array}$ & $\begin{array}{l}\text { Throughout } \\
\text { enclosure. Grids } \\
\text { N1W1, N1W0, } \\
\text { N1E0, and S1E0. }\end{array}$ & Trench 20 & 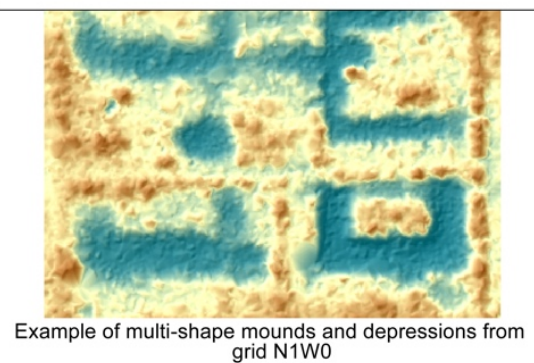 \\
\hline
\end{tabular}

Figure 4. Mound-Depression configurations identified at Ta Prohm based on lidar survey data. The dark blue areas are ponds/depressions, while the lighter brown color are higher elevation mound areas. 


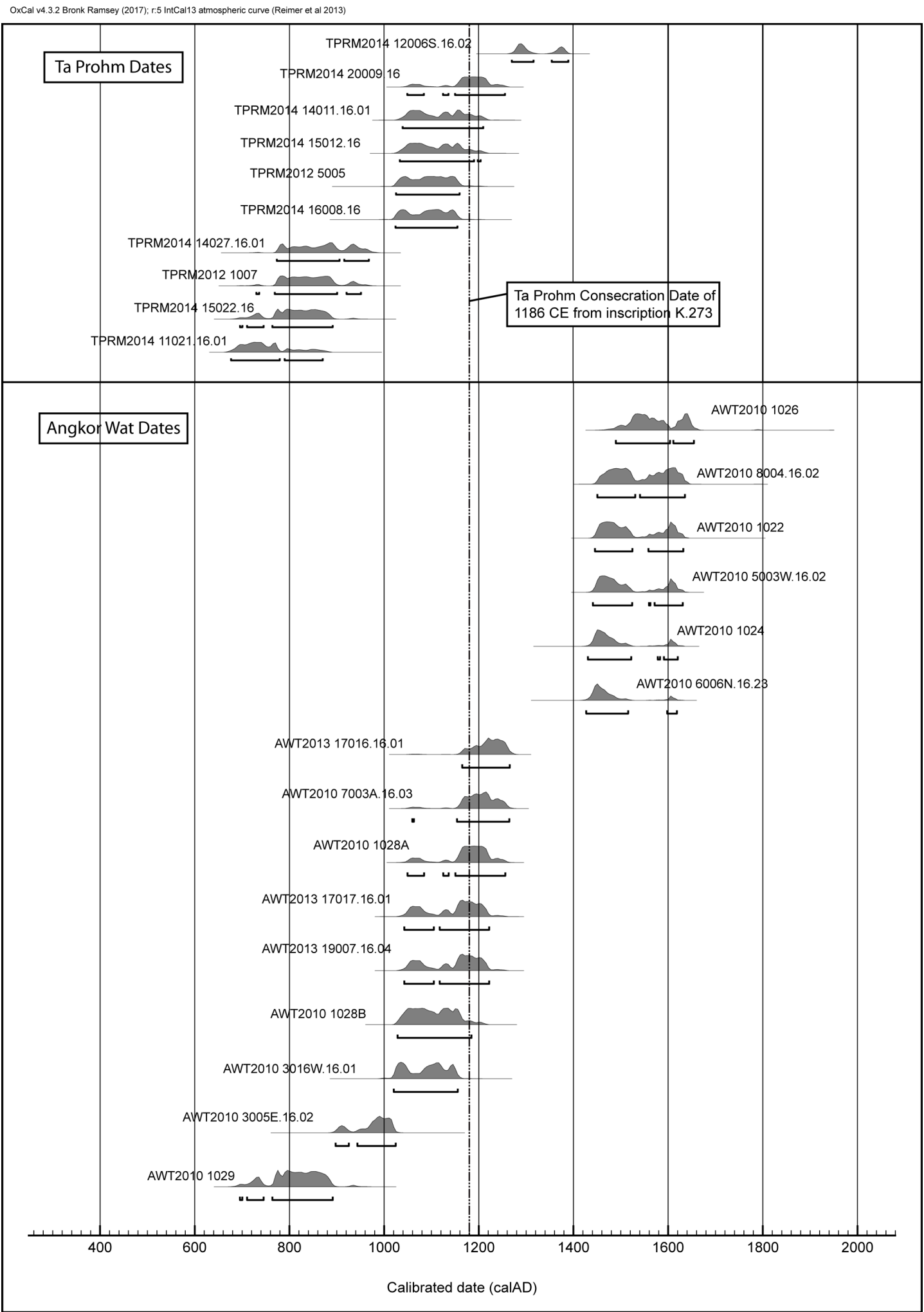

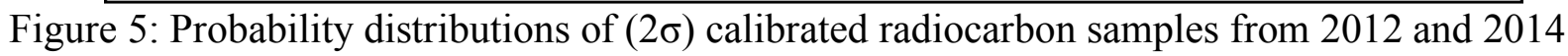
field seasons at Ta Prohm (top) and 2010 and 2013 field seasons at Angkor Wat (bottom). 


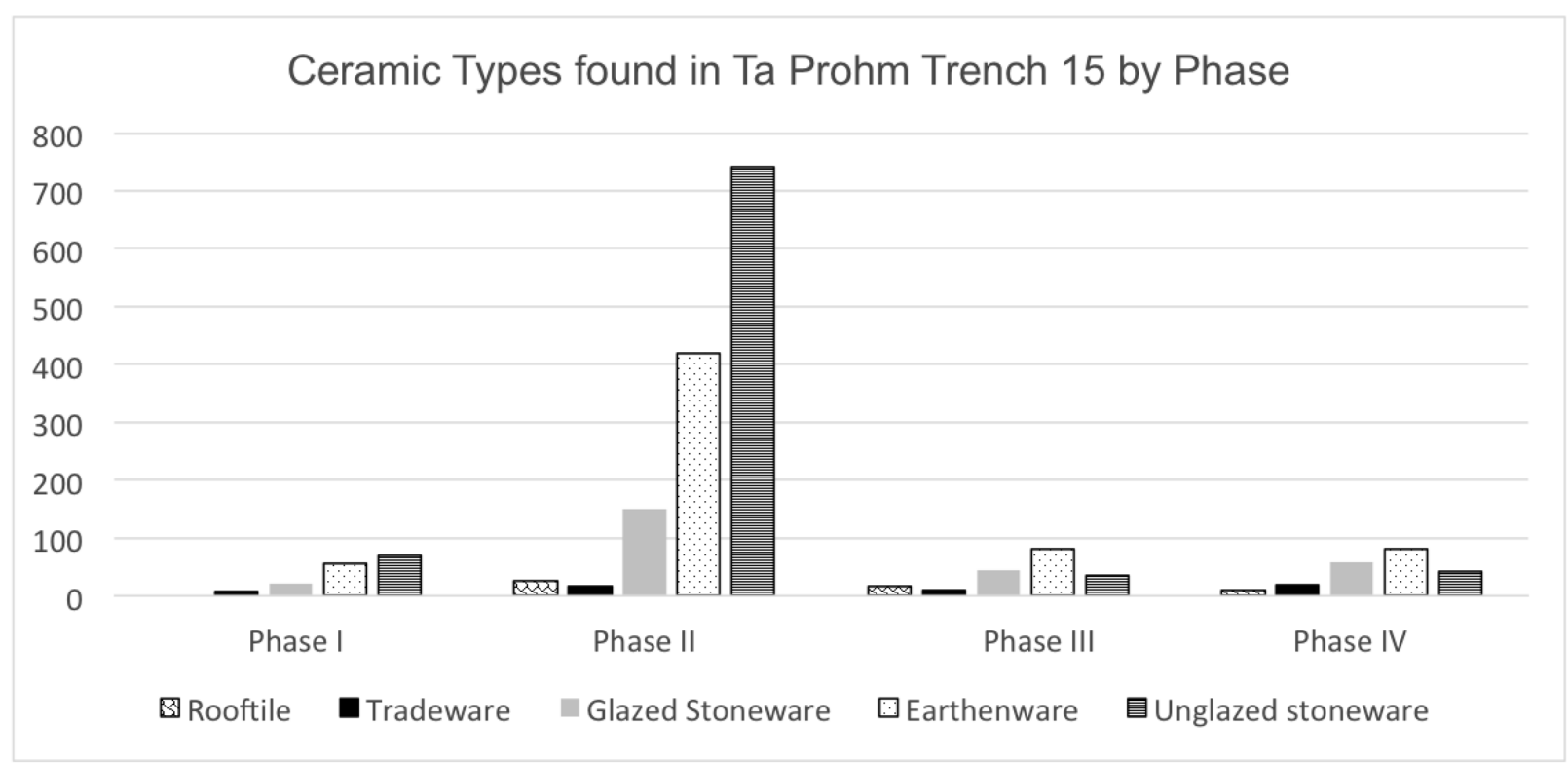

Figure 6: Different ceramic types found in Trench 15 at Ta Prohm. 


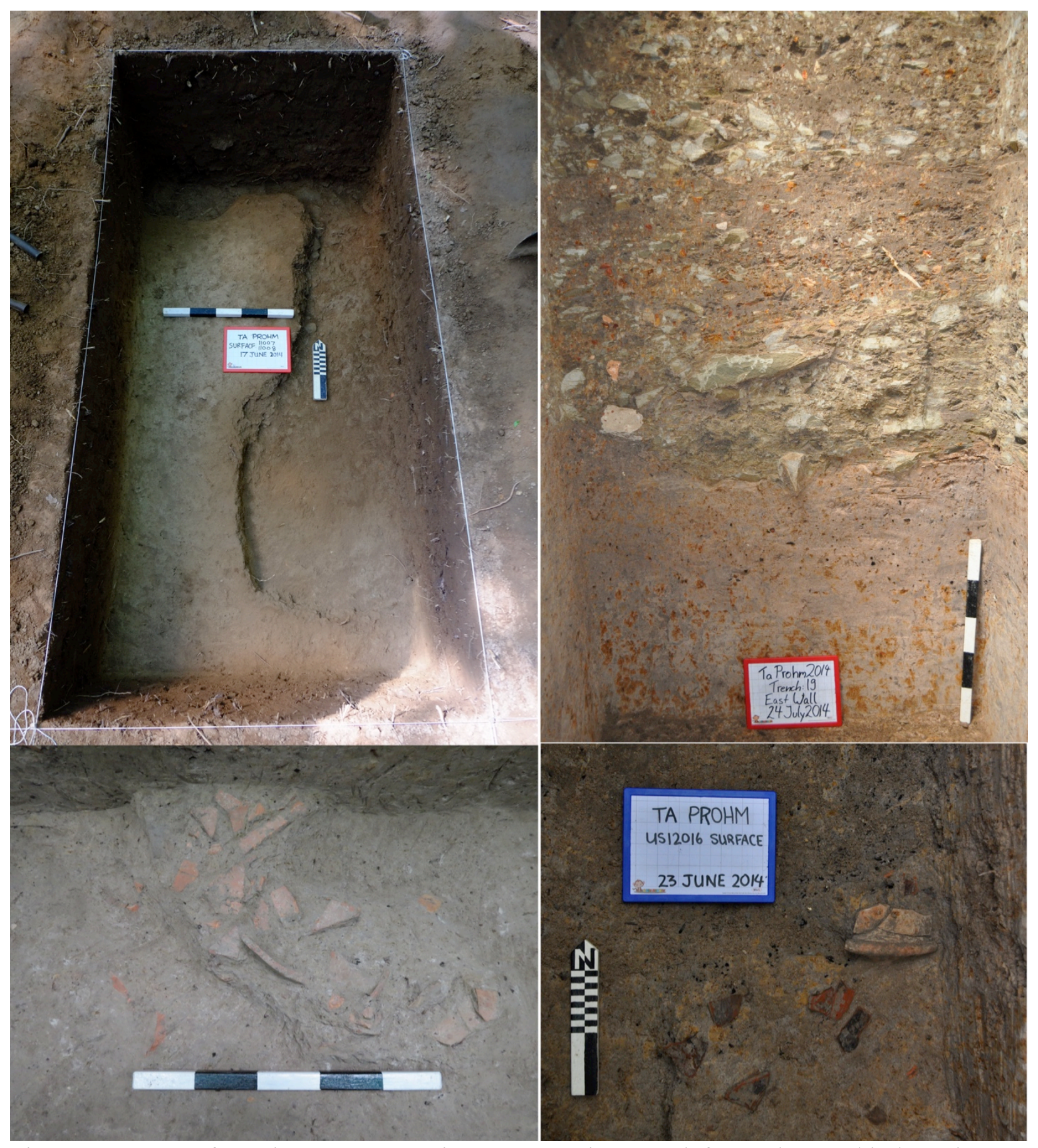

Figure 7: Features from the 2014 excavations at Ta Prohm. Top left: Sandstone chip layer in Trench 12; Top right: Profile of the East Wall of Trench 19 showing the thick sandstone chip layer in this unit; Bottom left: Ceramics concentration in Trench 15; Bottom right: ceramics concentration in Trench 12. 


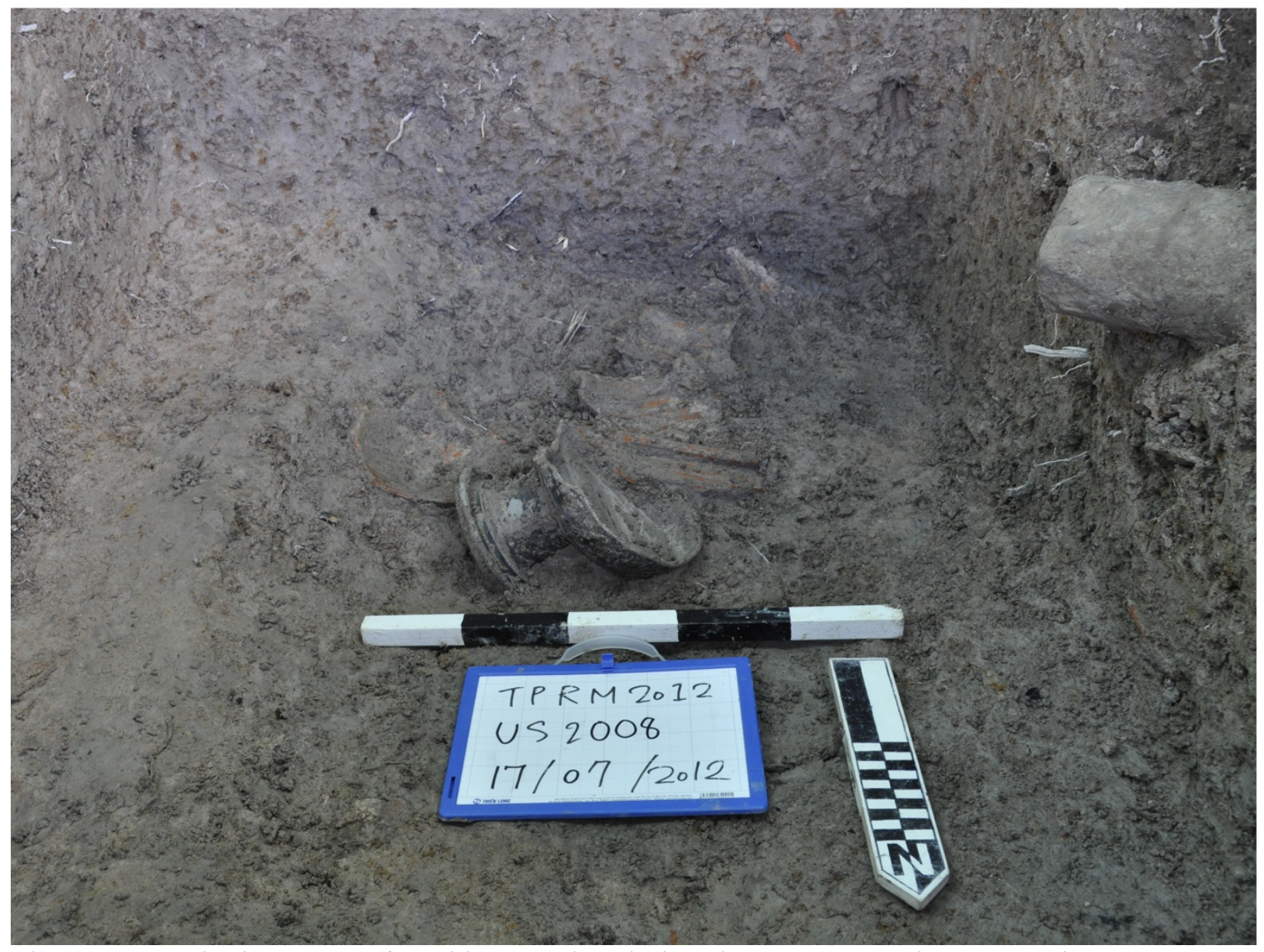

Figure 8: Trash pit contents found in Trench 2 during the 2012 Ta Prohm excavations. A sandstone spice mortar can be seen sticking out from the wall on the right. 


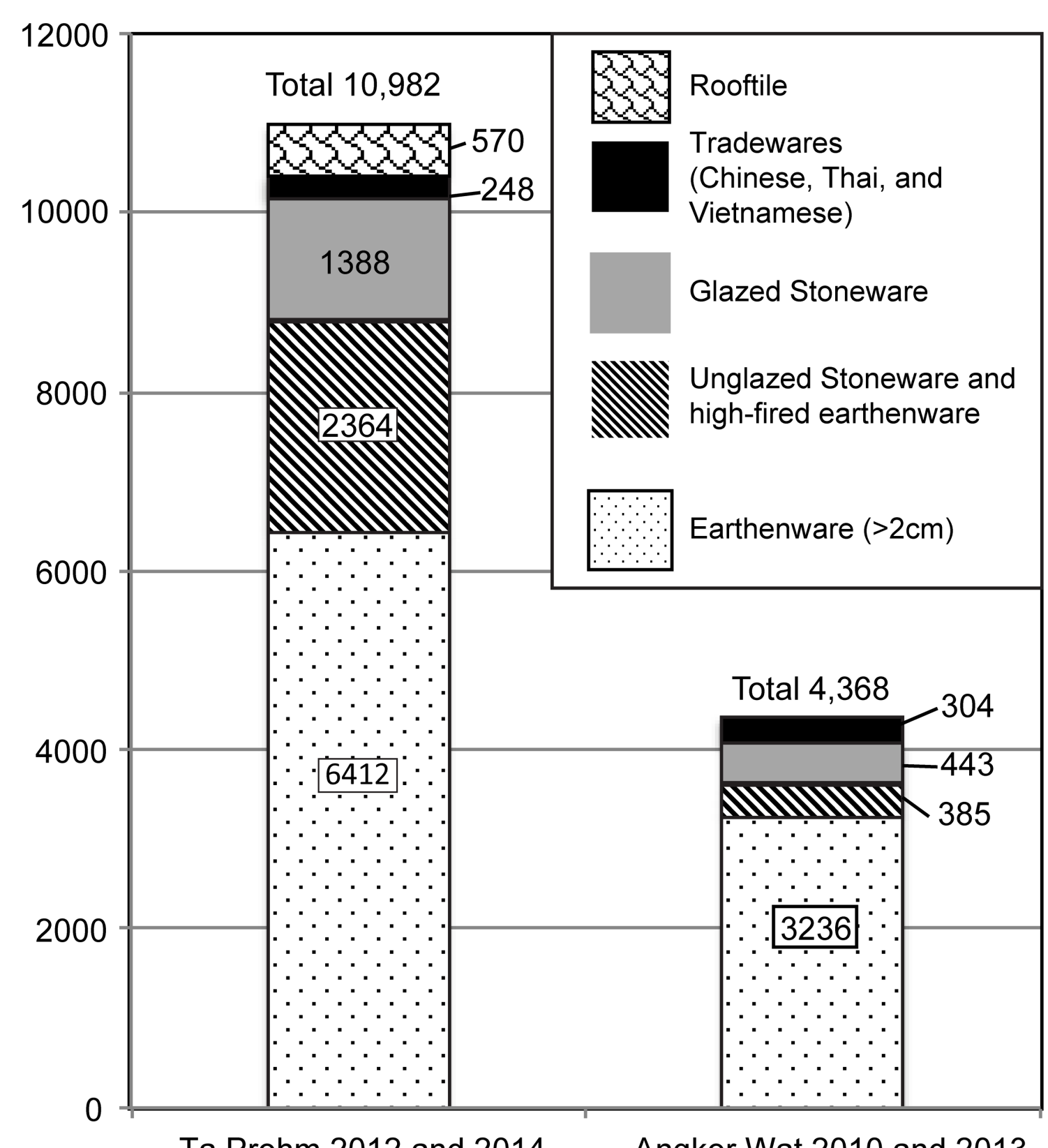

Ta Prohm 2012 and 2014

Angkor Wat 2010 and 2013

Figure 9: Ceramics bar chart comparing counts of ceramic types found at Ta Prohm and Angkor Wat. In both locations, ceramic sherds under $2 \mathrm{~cm}^{2}$ made up the bulk of the ceramic counts and are not included in this chart. This included 37\% of ceramics in the 2012 field season at Ta Prohm and over 50\% in the other field seasons at Ta Prohm and Angkor Wat. 